\title{
PENGUATAN JARINGAN PERPUSTAKAAN (NETWORKLIBRARY) SEBAGAI UNSUR POTENSIAL DALAM MENINGKATKAN AKSES LAYANAN PERPUSTAKAAN BAGI MAHASISWA UNIVERSITAS TERBUKA

\author{
Siti Samsiyah ${ }^{\left.1^{*}\right)}$ \\ Jurusan Ilmu Perpustakaan dan Kearsipan \\ Fakultas Ilmu Sosial dan Ilmu Politik Universitas Terbuka, Jakarta \\ *) Korespondensi: siti@ut.ac.id
}

\begin{abstract}
[Title: Strengthening Library Network Element Potential For Improving Access to Services for Students of Open University Library] Open University (UT) as a college long distance education has special characteristics within the learning system. Students and faculty are not intensively meet face-to-face every day. Assisted students in learning systems through a wide range of media that contains the lecture material. Variety of this medium as a means of learning includes, program computer assisted instruction (CAI), cleaning lib, audio-video, program-lbs sky tv channels, tv feature, radio feature. As a college concept Newspapers, there are different characteristics also in library services. Conventional college students can directly visit the library chooses, borrow library collections, but it also students can access all the collections atupun book collection over the internet. Conventional statistical data library visitors also showed a very high rating. While UT as distance education, students have limited access to the library collection off line / direct physical visits to the library. Because students are scattered throughout the country, practical collections that can be enjoyed direct visits by students who were in the location of Jakarta, Bogor, Depok, Tangerang and Bekasi (Jabodetabek.). Descriptive study with qualitative approach aims to identify the strengthening of the network library as an effort to improve access to library services for UT as a student library services for students Newspapers. With source data from UT students, librarians, and secondary data sources in the form of documentation and access to the collections of statistical data shows that the strengthening of the UT library network is indispensable for students. Among strengthening FKP2TN library network, Aspika (Association of organizers of Higher Education Library and Information Science Indonesia). This is to overcome the limitations of off line student access to the UT libraries while improving the quality of learning.
\end{abstract}

Keywords: PTJJ; Library Network; Academic Library.

\begin{abstract}
Abstrak
Universitas Terbuka (UT) sebagai perguruan tinggi jarak jauh (PTJJ) memiliki karakteristik khusus dalam sistem pembelajarannya.Mahasiswa dan dosen tidak bertemu secara intensif tatap muka setiap hari. Dalam sistem pembelajarannya mahasiswa dibantu melalui berbagai media yang berisi materi perkuliahan. Ragam media ini sebagai sarana pembelajaran meliputi, program computer assisted instruction (CAI), dry lib, audiovideo, program tv channel sky-lbs, tv feature, radio feature. Sebagai perguruan tinggi berkonsep PTJJ, terdapat karakteristik yang berbeda juga dalam layanan perpustakaannya. Kalau perguruan tinggi konvensional mahasiswa dapat secara langsung berkunjung ke gedung perpustakaan memilih, meminjam koleksi perpustakaan, selain itu juga mahasiswa dapat mengakses seтиa koleksi atupun memesan koleksi melalui internet. Sedangkan UT sebagai PTJJ, mahasiswa memiliki keterbatasan dalam mengakses koleksi perpustakaan secara off line/kunjungan langsung secara fisik ke perpustakaan. Karena mahasiswa yang tersebar di seluruh tanah air, praktis koleksi perpustakaan yang bisa dinikmati secara kunjungan langsung oleh mahasiswa yang berada di lokasi Jakarta, Bogor, Depok Tangerang dan Bekasi (Jabodetabek.). Penelitian deskriptif dengan pendekatan kualitatif ini bertujuan untuk mengidentifikasi penguatan jaringan perpustakaan sebagai upaya meningkatkan akses layanan perpustakaan bagi mahasiswa UT sebagai layanan perpustakaan bagi mahasiswa
\end{abstract}


PTJJ. Dengan sumber data dari mahasiswa UT, pustakawan, dan sumber data sekunder berupa dokumentasi akses koleksi perpustakaan dan data statistik menunjukkan bahwa penguatan jaringan perpustakaan UT sangat diperlukan bagi mahasiswa. Diantaranya penguatan jaringan perpustakaan FKP2TN (Forum Kerjasama Perpustakaan Perguruan Tinggi Negeri), Aspika (Asosiasi penyelenggara Pendidikan Tinggi Ilmu Perpustakaan dan Informasi Indonesia). Hal ini untuk mengatasi keterbatasan akses secara off line mahasiswa pada perpustakaan UT sekaligus meningkatkan kualitas pembelajaran.

\section{Kata kunci: PTJJ; Jaringan perpustakaan; perpustakaan perguruan tinggi.}

\section{Pendahuluan}

Perpustakaan merupakan jantung bagi sebuah perguruan tinggi, perguruan tinggi yang berkualitas didukung oleh perpustakaan yang berkualitas pula. Kualitas perpustakaan dapat dilihat dari sisi manajemen, jumlah dan jenis koleksi perpustakaan, kualitas pustakawan, serta sarana dan prasarananya. Untuk sarana dan prasaranya terdiri dari unsur lokasi perpustakan yang mudah dijangkau pengguna,serta kemampuan akses ke koleksi perpustakaan.Sarana lainnya adalah ruang sirkulasi, ruang baca buku, majalah, jurnal yang nyaman, ruang refernsi, penyimpanan audio visual. Selain sarana tersebut yang tidak kalah penting adalah fasilitas internet sebagai jalur media tercepat untuk mencari koleksi bahkan ada beberapa perpustakaan melayani peminjaman via internet ini.

Semakin berkembangnya teknologi memberikan peluang perpustakaan untuk meningkatkan perannya bukan saja sebagai pusat sumber belajar namun lebih dari itu perpustakaan sebagai pusat sumber penelitian, dan berlangsungnya proses knowledge management. Di perpustakaanlah terjadi proses pertumbuhan pengetahuan yang terus berkelanjutan. Dan bertambah hari volume peminjaman koleksi-pengembalian, akses jurnal tercetak dan elektronik semakin tinggi frekuensinya.

UniversitasTerbuka (UT) merupakan perguruan tinggi jarak jauh (PTJJ). Terdapat perbedaan yang signifikan antara perguruan tinggi konvensional dan perguruan tinggi jarak jauh. Pada perguruan tinggi jarak jauh terjadi proses pembelajaran yang terpisah antara dosen dan mahasiswa, sebagai sarana pembelajaran mahasiswa dapat menggunakan beragam media untuk mempelajari materi pembelajaran. Media yang disediakan oleh UT meliputi, audio-video, siaran tv channel, dry lab, i-TV, CAI (computer assistance instruksional), radio feature, tv feature. Semua fasilitas pembelajaran yang berbasis audio-video ini dapat diakses secara gratis oleh mahasiswa UT, pada laman http://www.ut.ac.id. Disamping fasilitas tersebut UT juga menyediakan perpustakaan digital koleksi yang dapat dinikmati oleh mahasiswa meliputi ruang baca virtual, jurnal elektronik, catalog online, e-book, I-Tv, dan sumber belajar lain yang terhimpun dalam OER (Open Education Resources). Berikut laman perpustakaan UniversitasTerbuka (UT) yang dapat diakses oleh seluruh mahasiswa UT yang tersebar di seluruh tanah air, dan mahasiswa yang berdomisili di negara lain. 


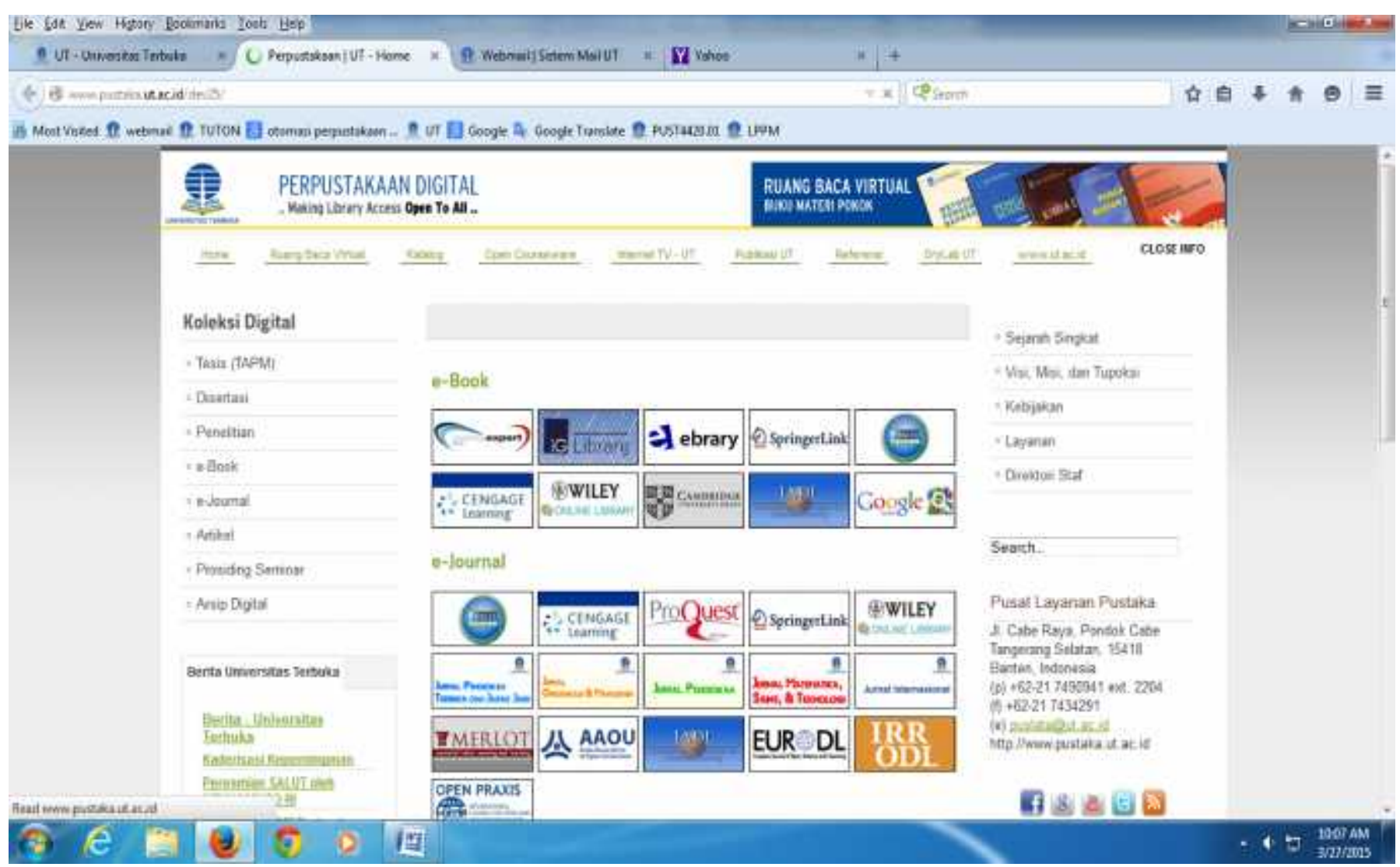

Gambar 1. Tampilan Laman Perpustakaan Digital Universitas Terbuka

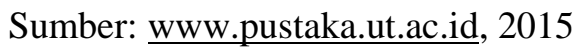

Melihat jenis koleksi perpustakaan yang berada di perpustakaan -UT, jumlah koleksi serta fasilitas akses berupa media internet perpustakaan UT menunjukkan bahwa koleksi perpustakaan -UT selain memedai juga mudah dijangkau. Namun dari sisi frekuensi pemanfaataan koleksi perpustakaan terutama kunjungan langsung mahasiswa ke perpustakaan UT masih tergolong rendah. Dengan jumlah mahasiswa sekitar 400.0000 ribu mahasiswa, akses ke perpustakaan UT secara off line- sepanjang tahun 2014 dapat dilihat pada data table berikut ini :

Tabel 1 Jumlah Pengunjung Perpustakaan Universitas Terbuka Tahun 2014

Sumber: Perpustakaan Universitas Terbuka, 2014

\begin{tabular}{|l|c|c|c|c|c|c|c|c|}
\hline \multirow{3}{*}{ Bulan } & \multicolumn{3}{|c|}{ UT } & \multicolumn{2}{c|}{ NON UT } & \multicolumn{3}{c|}{ Jumlah Pengunjung } \\
\cline { 2 - 9 } & \multicolumn{2}{|c|}{ Karyawan } & \multirow{2}{*}{ Mahasiswa } & Umum & Mahasiswa & UT & NON UT & Total \\
\cline { 2 - 10 } & Fakultas & Unit Lain & & 3 & 192 & 86 & 195 & 281 \\
\hline JANUARI & 17 & 4 & 65 & 15 & 155 & 61 & 170 & 231 \\
\hline PEBRUARI & 30 & 6 & 25 & 35 & & & & \\
\hline
\end{tabular}




\begin{tabular}{|l|l|l|l|l|l|l|l|l|} 
MARET & 19 & 5 & 43 & 13 & 202 & 67 & 215 & 282 \\
\hline APRIL & 18 & 9 & 21 & 16 & 197 & 48 & 213 & 261 \\
\hline MEI & 11 & 5 & 15 & 20 & 197 & 31 & 217 & 248 \\
\hline JUNI & 18 & 4 & 6 & 24 & 245 & 28 & 245 & 297 \\
\hline JULI & 15 & 3 & 3 & 6 & 95 & 21 & 101 & 122 \\
\hline AGUSTUS & 15 & 7 & 17 & 13 & 62 & 39 & 75 & 114 \\
\hline SEPTEMBER & 40 & 13 & 23 & 13 & 163 & 76 & 176 & 252 \\
\hline OKTOBER & 15 & 15 & 31 & 11 & 146 & 61 & 157 & 218 \\
\hline NOVEMBER & 16 & 12 & 14 & 11 & 120 & 42 & 131 & 173 \\
\hline DESEMBER & 33 & 9 & 7 & 7 & 87 & 49 & 94 & 143 \\
\hline \hline JUMLAH & $\mathbf{2 4 7}$ & $\mathbf{9 2}$ & $\mathbf{2 7 0}$ & $\mathbf{1 5 2}$ & $\mathbf{1 8 6 1}$ & $\mathbf{6 0 9}$ & $\mathbf{1 9 8 9}$ & $\mathbf{2 6 2 2}$ \\
\hline \hline
\end{tabular}

Dari data di atas teridentifikasi untuk pengunjung perpustakaan UT secara off line masih rendah berbeda jauh dengan akses ke perpustakaan UT secara online mencapai 120.000 pengunjung. Secara sederhana jumlah pengguna perpustakaan -UT yang melakukan akses ke perpustakaan tercantum pada table berikut ini.

Tabel 2 Jenis Akses Pengunjung ke Perpustakaan Universitas Terbuka sumber : Perpustakaan Universitas Terbuka, 2014

\begin{tabular}{|l|c|}
\hline \multicolumn{1}{|c|}{$\begin{array}{c}\text { Jenis kunjungan ke perpustakaan } \\
\text { Universitas Terbuka }\end{array}$} & Jumlah pengunjung \\
\hline $\begin{array}{l}\text { Kunjungan perpustakaan secara off } \\
\text { line/kunjungan ke gedung perpustakaan UT }\end{array}$ & 2.622 pengunjung \\
\hline Kunjungan perpustakaan secara on line & 120.000 pengunjung \\
\hline
\end{tabular}

Tingginya akses ke perpustakaan UT secara online dikarenakan kemajuan teknologi yang telah dimanfaatkan oleh sebagain besar mahasiswa UT. Hal ini disebabkan cukup variasinya materi berformat elektronik yang dapat dinikmati secara online di perpustakaan UT, meliputi fasilitas ruang baca virtual (RBV) yang didalamnya berisi materi modul secara keseluruhan yang ada di 35 program studi yang ada di UT, mulai dari modul DII, DIII, D-IV, sarjana, hingga program pascasarjana, e-book, e-journal, juga koleksi multimedia. Dengan panduan pemanfaatan perpustakaan secara online yang tercantum dalam web-site perpustakaan akan mempermudah setiap pengguna memanfaatkan koleksi perpustakaan. Hal ini sesuai dengan penelitian yang dilakukan oleh Supsiloani (2006) yang menyatakan bahwa pemanfaatan perpustakaan 
secara elektronik sangat praktis dan efisien namun diperlukan tatacara akses informasi perpustakaan yang perlu dipahami oleh semua pengguna untuk memanfaatkan koleksinya.

Menurut Imran Benawi (2009) menyebutkan tujuan perpustakaan perguruan tinggi

1. Memenuhi keperluan informasi masyarakat perguruan tinggi, lazimnya saf pengajar dan mahasiswa juga tenaga adminsitrasi pergruan tinggi.

2. Menyediakan bahan pustaka rujukan pada semua tingkat akademis artinya mulai dari mahasiswa tahun pertama hingga mahasiswa pasca sarjana serta pengajarnya.

3. Menyediakan ruang belajar untuk pemakai perpustakaan

4. Menyediakan jasa peminjaman yang tepat guna bagi berbagai jenis pemakai

5. Menyediakan jasa informasi aktif yang tidak saja terbatas pada lingkungan perguruan tinggi terkait tapi juga lembaga industry local.

Penjelasan di atas telah mampu mendeskripsikan fungsi dan peran perpustakaan sebagai jantung perguruan tinggi.Maka perpustakaan harus mampu mendorong, memotivasi dan menyediakan berbagai sumber belajar serta terus meningkatkan akses ke koleksi perpustakaan bagi penggunanya.

Melihat dari rendahnya pemanfaatan perpustakaan UT oleh mahasiswa terutama pengguna off line atau kunjungan secara langsung, diperlukan upaya untuk meningkatkan fasilitas layanan perpustakaan UT.Tujuan dari penelitian ini adalah meningkatkan kualitas layanan perpustakaan UT melalui penguatan jaringan perpustakaan yang ada, antara lain FKP2TN (Forum Kerjasama Perpustakaan Perguruan Tinggi Negeri ) dan Asosiasi Penyelenggara Pendidikan Tinggi Ilmu Perpustakaan dan Informasi Indonesia (Aspika). Melalui hasil penelitian ini akan diperoleh gambaran manfaat penguatan jaringan perpustakaan yang tergabung dalam FKP2TN (Forum Kerjasama Perguruan Tinggi Negeri) dan Aspika (Asosiasi Perguruan manfaat serta identifikasi formula untuk mengembangkan fasilitas layanan perpustakaan khusunya bagi perguruan tinggi yang menerapkan konsep jarak jauh.

\section{Metode Penelitian}

Untuk memperoleh gambaran secara faktual kondisi fasilitas akses ke koleksi perpustakaan-UT, serta mengupayakan peningkatan kualitas layanan perpustakaan-UT digunakan metode deskriptif dengan pendekatan kualitatif. Metode ini sesuai untuk memperoleh kondisi yang sebenarnya mengenai fasilitas layanan yang ada di perpustakaan-UT, jumlah dan jenis koleksi yang ada, pengguna yang mengakses koleksi perpustakaan secara off line maupun online serta mengupayakan penguatan jaringan perpustakaan (networklibrary) untuk meningatkan kualitas layanan bagi perpustakan UT. Mengingat jumlah mahasiswa UT sangat besar mencapai 400.000 orang serta sebaran domisili mahasiswa yang ada di seluruh tanah air, serta negaranegara lain, perlu diidentifikasi penguatan jaringan perpustakaan untuk membantu dalam proses pembelajaran mahasiswa. 
Pendekatan kualitatif adalah untuk mendapatkan informasi secara detail dengan informan mahasiswa yang melakukan akses ke perpustakaan -UT, serta pustakawan-UT. Dari data yang terkumpul ini akan disintesakan hasilnya berupa narasi yang menjelaskan kondisi kualitas layanan perpustakaan UT, jumlah dan frekuensi pengguna yang mengakses koleksi perpustakaan UT, software yang digunakan, sumber daya manusia yang mengelola koleksi perpustakaan UT.

\section{Hasil Dan Pembahasan}

\subsection{Kondisi Faktual Kualitas Layanan Perpustakaan UT}

Perpustakaan Perguruan tinggi Terbuka (UT) memiliki koleksi terdiri dari seperti yang ada dalam rincian sebagai berikut:

Tabel 3 Jenis Koleksi Perpustakaan Universitas Terbuka

Sumber: Perpustakaan Unversitas Terbuka, 2014

\begin{tabular}{|c|c|c|}
\hline No & Koleksi & Keterangan \\
\hline 1 & Tesis & \\
\hline 2 & Disertasi & \\
\hline 3 & Penelitian & \\
\hline 4 & e-book & $\begin{array}{l}\text { iG Publish Busines Expert } \\
\text { iG Library } \\
\text { eBray } \\
\text { Gale Virtual Reference Library } \\
\text { SpringerLink } \\
\text { Cambridge University Press } \\
\text { Ebsco } \\
\text { Free Access } \\
\text { Guideline for open educational resources }\end{array}$ \\
\hline 5 & e-jurnal & $\begin{array}{l}\text { Jurnal terbitan UT ( jurnal organisasi dan } \\
\text { management, Jurnal Pendidikan, Jurnal } \\
\text { Matematika, Sains dan Teknologi } \\
\text { Cengange Learning } \\
\text { Ebsco Host } \\
\text { ProQuest }\end{array}$ \\
\hline 6 & Artikel & \\
\hline 7 & Prosiding Seminar & Merupakan proisding seminar yang diadakah \\
\hline
\end{tabular}




\begin{tabular}{|l|l|}
\hline & $\begin{array}{l}\text { oleh } 4 \text { fakultas yang ada di UT dan } \\
\text { berlangsung setiap tahun }\end{array}$ \\
\hline
\end{tabular}

Dari data diatas, perpustakaan UT telah memiliki jumlah koleksi yang memadai bagi mahasiswa untuk membantu dalam proses belajarnya. Selain bahan pustaka tercantum pada table diatas, mahasiswa UT juga sangat terbantu dengan adanya RBV (Ruang Baca Virtual), merupakan fasilitas layanan digital yang ada di perpustakaan UT berupa layanan baca untuk semua modul yang diguankan di UT. Untuk mengaksesnya sangat mudah, cukup mengetik nama dan tanggal lahir maha mahasiswa dapat mengakses fasilitas RBV selama 24 jam, 365 hari. Namun kendalanya bagi daerah yang tidak memiliki jaringan pita magnetic/jalur internet, maka mereka tidak bisa mengakses fasilitas RBV maupun fasilitas lainnya yang ada di perpustakaan dalam format digital.

Berikut gambaran pengakses perpustakaan UT selama kurun waktu 2014 (dalam waktu 12 bulan ) dapat dilihat pada grafik berikut ini.



Gambar 2 Rincian Statistik Pengakses Perpustakaan Universitas Terbuka Tahun 2014 Sumber: Perpustakaan Universitas Terbuka, 2014

Dari grafik di atas teridentifikasi pengakses perpustakaan UT secara online mencapai 120.000 pengakses hal ini menunjukkan bahwa tingkat kebutuhan informasi bagi mahasiswa UT sangat tinggi. Kehadiran perpustakaan bagi mahasiswa dirasakan sangat penting, apalagi UT sebagai perguruan tinggi jarak jauh sangat diperlukan dukungan dari perpustakaan untuk membantu mahasiswa dalam proses pembelajaran. 
Berikut cuplikan dari jawaban mahasiswa S1-Ilmu Perpustakaan dan mahasiswa Diploma II Ilmu perpustakaan UT mengenai keberadaan perpustakaan UT.

"Saya selaku mahasiswi UT yang berasal dari daerah Situbondo - Jawa timur, tidak mungkin datang / berkunjung ke perpustakaan perguruan tinggi yang UT sediakan. Akan tetapi, saya dapat merasakan salah satu layanan yang diberikan UT yaitu perpustakaan digital atau dapat juga dikatakan perpustakaan maya. Dengan begitu canggihnya, sehingga sangat membantu dan memudahkan saya dalam melakukan penelusuran literatur / mencari informasi yang sangat mutakhir, dengan cukup berkunjung di situs / web site perpustakaan UT melalui bantuan Internet. Dengan demikian, saya selaku mahasiswi UT tetap sangat merasakan pelayanan Perpustakaan Perguruan Tinggi yang telah UT berikan" (Aisyatin Hani'ah/022509154/Situbondo)

"Saya sangat mengharapkan akses yang lebih mudah dalam layanan perpustakaan UT. Saya juga sering mengakses koleksi perpustakaan yang ada di laman UT. namun, saya lebih banyak mengakses Dry Lab, Jurnal, Artikel dan Perkiraan Soal-Soal Ujian, karena akses ke Buku Materi Elektronik / yang diakses secara streaming sering tidak dapat/lambat sekali aksesnya (terutama daerah tempat saya tinggal). Juga jika diakses melalui mobile, terkadang browser yang digunakan tidak kompatibel. Tapi secara keseluruhan saya sangat menyukai layanan perpustakaan yang ada di laman UT, khususnya artikel dan jurnal yang ada di dalamnya sangat membantu dan menambah wawasan”.(Nurul Ardiana 018031684 /Tenggarong)

"Sebagai mahasiswa tentu sangat mengharapkan layanan perpustakaan-UT dengan mudah dapat diperoleh, apalagi UT hampir tidak ada tatap muka jadi tentu saja sangat membutuhkan informasi yang cepat dan lengkap. Saya sering mengakses koleksi yang ada di perpustakaanUT, manfaatnya saya mendapatkan informasi yang terbaru tiap saat”. (Rahman Yani/Jakarta 0155822)

"Setuju untuk dapat mengakses e-book perpustakaan UT diharapkan gratis, setiap mahasiswa yang mengambil mata kuliah tertentu secara otomatis bisa mengakses e-book tentang Mata kuliah tersebut. Bagi yang tidak bisa mengakses karena kendala teknologi (tidak bisa akses internet, tidak punya komputer atau laptop) disediakan juga hardcopy bukunya sebagaimana yang berjalan selama ini untuk membelinya.Diharapkan pemerintah mensupport kebutuhan ini demi kecerdasan bangsa. Sehingga Perpustakaan sebagai jantung Perguruan tinggi sebagai jantung yang sehat dan vital”.(Tri Mulyati/ Yogyakarta 017628765) 
Pendapat mahasiswa mengenai kebaradaan perpustakaaan UT semuanya menyatakan bahwa mereka sangat memerlukan kehadiran perpustakaan, lengkap dengan koleksi yang ada di dalamnya dapat diakses dengan mudah setiap saat. Namun karena UT sebagai perguruan tinggi jarak jauh mahasiswa memiliki keterbatasan untuk mendapatkan sumber belajar yang ada di perpustakaan

Berdasarkan diperlukannya kehadiran perpustakaan di perguruan tinggi, khususnya UT sebagai perguruan tinggi jarak jauh yang memiliki keterbatasan dalam mengakses koleksi perpustakaan maka diperlukan penguatan jaringan perpstakaan perguruan tinggi yang tergabung dalam FKP2TN dan Aspika. (Suwarno, Wiji \& Miswan, 2014 : 10) mengemukakan alasan yang mendasari perpustakaan perlu membentuk jaringan kerjasama, adalah .

1. Terjadinya peningkatan jumlah buku yang diterbitkan, sementara anggaran perpustakaan untuk pengadaan buku masih terbatas.

2. Era saat ini terbitan tidak hanya dalam bentuk buku, melainkan bantuk media lainpun diterbitkan juga, sehingga semakin banyaknya jenis media yang diterbitkan ini kerjasama jaringan antar perpustakan pun dirasakan semakin penting.

3. Berkembanganya ilmu pengetahuan dan teknologi memberikan tuntutan kepada masyarakat untuk mengikutinya, maksudnya jaringan kerjasama perpustakaan perlu dilakukan karena kebutuhan informasi dari pengguna meningkat.

4. Dalam hal akses informasi masyarakat kota tidaklah menglami kesultan misalnya untuk akses informasi perpustakaan melalui intrenet terdapat warnet disegala tempat, took buku mudah ditemui. Dengan asumsi setiap pengguna perpustakaan memiliki akses yang sama maka diperlukan jaringan kerjasama perpustakaan.

5. Kemajuan IPTEK telah menggeser paradigm perpustakaan yang semula disebut sebagai gudang buku. Adanya teknologi sangat membantu dalam mengakses informasi inilah diperlukan jaringan perpsuataan.

6. Untuk menciptakan penghematan pembangunan perpustakaan biaya sangat mahal, dengan kerjasama antar perpustakan inilah bisa dihemat pembiayaan tersebut.

Dengan mencermati pendapat dari pakar ilmu perpustakaan di atas cukup memberikan alasan sangat diperlukannya penguatan jaringan perpustakaan.

Sebagai upaya meningkatkan kualitas pembelajaran di UT maka perlu ditingkatkan kerjasama perpustakaan UT dengan mitra dalam hal ini adalah jaringan FKP2TN dan Aspika. Melalui kedua jaringan ini mahasiswa UT yang berada di daerah terpencil yang tidak bisa mengakses perpustakaan UT melalui fasilitas internet dapat menikmati perpustakaan dengan mengunjungi perguruan tinggi yang ada di lingkup jaringan FKP2TN dan Aspika. 


\subsection{Kondisi Jaringan FKP2TN}

Forum Kerjasama Perpustakaan Perguruan Tinggi (FKP2TN) merupakan forum komunikasi perpustakaan yang ada di lingkup perguruan tinggi. Organisasi ini berdiri lebih dari 20 tahun, informasi yang dirilis dari www.fkp2tn.org (tanggal 7 Aril 2015) menyebutkan bahwa anggota FKP2TN telah mencapai 61 perpustakaan tinggi negeri, universitas, institute, sekolah tinggi, politeknik, yang bernaung dibawah Kementrian Pendidikan dan Kebudayaan/sekarang Kemenristek-Dikti, Kementrian Agama. Jika mencermati sebaran anggota dari FKP2TN akan membantu mahasiswa dalam mengakses informasi pada sumber yang tersimpan di perpustakaan. Jaringan kerjasama antar perpustakaan ini sangat besar manfaatnya jika digunakan oleh mahasiswa.

\subsection{Kondisi Jaringan ASPIKA}

Aspika merupakan organisasi asosiasi penyelenggara perguruan tinggi ilmu perpustakaan informasi dan kearsipan yang ada di Indonesia hingga saat ini anggota Aspika cukup banyak - baik perguruan tinggi maupun perguruan tinggi negeri yang di dalamnya terdapat prodi Ilmu pepustakaan, kearsipan dan informasi. Dengan memanfaatkan jaringan Aspika mahasiswa UT memiliki banyak pilihan dalam mengakses informasi.

\subsection{Model Penguatan Jaringan Perpustakaan (network library) Untuk Meningkatkan Kualitas Layanan Perpustakaan UT}

Model penguatan jaringan merupakan perpaduan atau sinergi antara perpustakaan yang tergabung dalam FKP2TN dengan perpustakaan yang tergabung dalam Aspika. Tergabungnya dua jaringan perpustakaan terbesar di Indonesia ini selaras dengan kondisi sebaran mahasiswa UT yang berada di seluruh penjuru tanah air. Dengan melihat kondisi dari jumlah anggota-sebaran perpustakaan yang ada di FKP2TN dan Aspika akan sangat membantu bagi mahasiswa UT untuk mendapatkan informasi yang berkualitas dari fasilitas perguruan tinggi yang ada di PTN. Perpustakaan PTN lebih maju karena dari sisi biaya disediakan oleh pemerintah, dengan sistem pengadaan yang didasarkan pada kebutuhan pengguna terutama bagi civitas akademika-perguruan tinggi bersangkutan. Berikut ini adalah contoh model jaringan perpustakaan yang dibangun pada jaringan GDL -Network (Indonesia Digital Library network) 


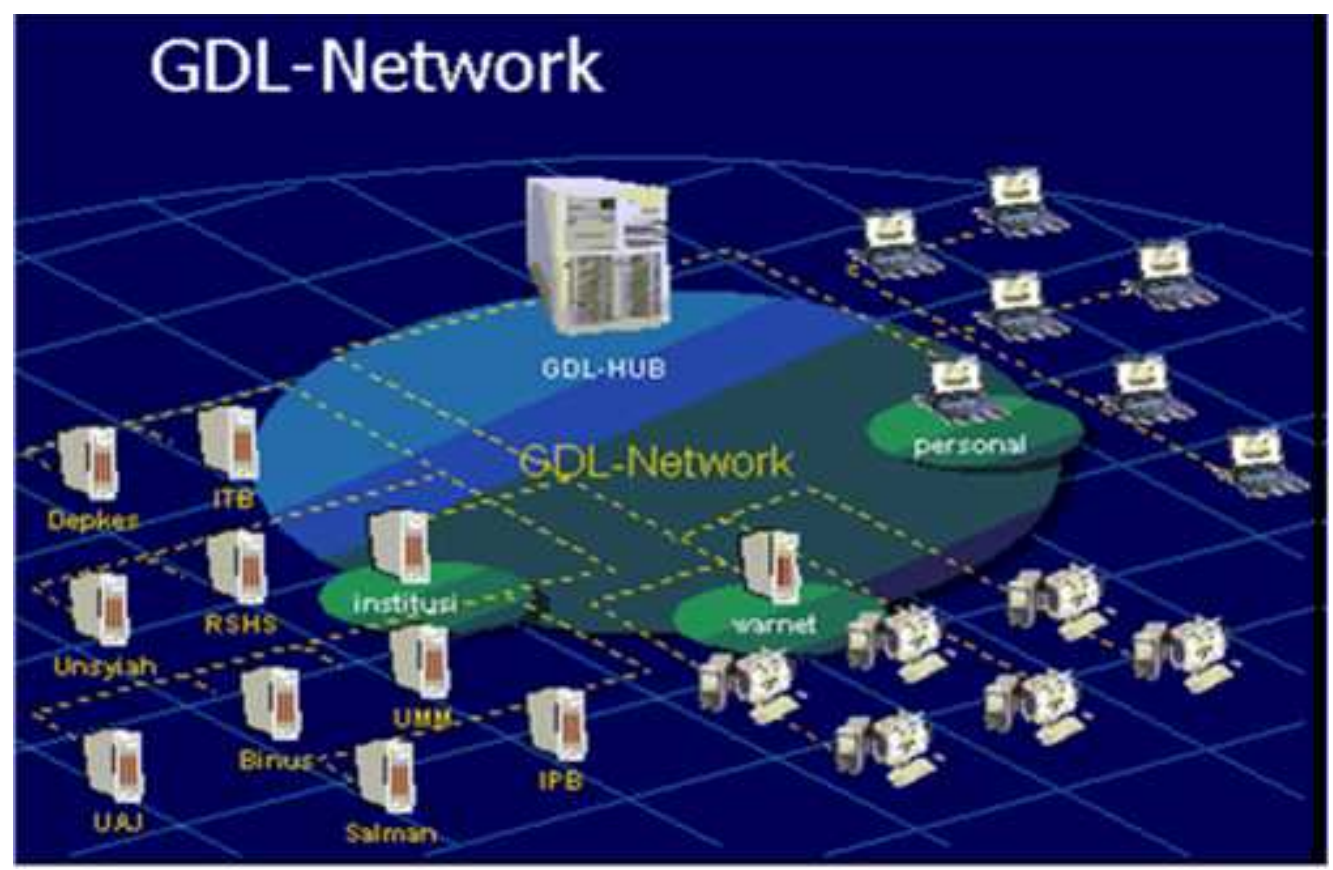

Gambar 3. Skema Jaringan Ganesha Digital Library

Sumber :http://tentang-semua.blogspot.com/2012/10/pengertian-idln-indonesia-digital.html, 2015

Berasumsi dengan model jaringan GDL-Network maka pengembangan untuk penguatan jaringan FKP2TN dan Aspika sangat potensial untuk memberikan kemudahan akses informasi ke perpustakaan bagi mahasiswa UT secara keseluruhan, bagi mahasiswa yang berdomisili di wilayah tanah air maupun mahasiswa yang tinggal di negara-negara lain. Pemanfaatan kedua jaringan perpustakaan tersebut sekaligus melayani mahasiswa dalam dua bentuk secara online maupun secara off line dengan pilihan perpustakaan mencapai sekitar 80 perpustakaan perguruan tinggi. Dengan pilihan perpustakaan yang beraneka ragam, lokasi yang tersebar di seluruh Indonesia secara online dan offline peningkatan literasi informasi dengan pemanfaatan sumber informasi di perpustakaan bagi mahasiswa UT akan cepat tercapai.

\section{Simpulan}

Penguatan jaringan perpustakaan UT dengan jaringan perpustakaan FKP2TN dan Aspika perlu dirintis dan dihidupkan kembali.Dengan kartu Sakti yang dimiliki oleh mahasiswa UT. Melalui fasilitas kartu Sakti inilah mahasiswa dapat menikmati lebih dari 60 perpustakaan yang ada di Perguruan Tinggi yang tersebar di seluruh Indonesia. Begitu pula dengan penguatan jaringan Perpustakaan-UT dengan jaringan perpustakaan Aspika akan menambah kemudahan bagi mahsiswa UT untuk melakukan akses informasi dengan cepat dan mudah. Sehingga mahasiswa UT memiliki kelebihan yang luar bisa dalam mengakses sumber-sumber informasi, selain perpustakan UT sendiri 
yang telah mampu menyediakan sumber informasi secara lengkap baik berbasis manual maupun digital. Dengan ditambahkan masuknya kedua jaringan perpustakaan tersebut akan lebih mengoptimalkan mahasiswa Universitas Terbuka (UT) dalam proses pembelajarannya.

\section{Daftar Pustaka}

Benawi, Imran. Fungsi Perpustakaan Dalam Memotivasi Belajar. Jurnal Perpustakaan danInformasi -UIN Sumatera Utara, Iqra', Vol 03 No. 02, Oktober 2009)

Laksmi. 2012. Interaksi Pretasi dan Makna (Pengantar Analisis Mikro Untuk Penelitian di Bidang Ilmu Informasi dan Ilmu Terapan lainnya).Bandung : Karya Putra Darwati

Suwarno, Wiji dan Miswan.2014. Jaringan Kerjasama Perpustakaan dan Informasi. (Buku Materi Pokok PUST 4316). Jakarta : Penerbit Universitas Terbuka

Supsiloani. 2006. Perpustakaan Digital sebagai Wujud Penerapan Teknologi Informasi diPerguruan Tinggi. Pustaha : Jurnal Studi Perpustakaan dan Informasi, Vol 2, No. 1

\section{Daftar Web}

Laman Universitas Terbuka http://www.ut.ac.id.

Laman FKP2TN http: // www.fkp2tn.org ( akses tanggal 7 April 2015)

Laman http://tentang-semua.blogspot.com/2012/10/pengertian-idln-indonesia-digital.html (akses 2015) 